\title{
1. FORAMINIFERA FROM DSDP SITE 370, LEG 41, EASTERN NORTH ATLANTIC OCEAN
}

\author{
F.M. Gradstein, Atlantic Geoscience Centre, Bedford Institute of Oceanography, Dartmouth (N.S.), Canada
}

\begin{abstract}
Foraminifera in 12 composite samples from DSDP Site 370 , Leg 41, eastern North Atlantic Ocean are of Valanginian through Cenomanian and Eocene through Quaternary age. The Lower Cretaceous deposits of Site 370 lack the epistominids, commonly found on the Canadian Atlantic continental margin in coeval sediments.
\end{abstract}

\section{INTRODUCTION}

Deep Sea Drilling Project Site 370, Leg 41, was located off Morocco in a water depth of 4216 meters and penetrated 1176.5 meters of sediment before bottoming in Lower Cretaceous strata.

Thirty-four samples were analyzed for foraminiferal content. Due to very small sample size, where possible, samples from the same lithologic unit were lumped to form the composite samples shown in Table 1. Despite the small size, an attempt has been made to date the samples; the results are discussed in descending stratigraphic order. The Tertiary zone designations, where possible, follow Blow (1969); the Cretaceous zones are expressed in van Hinte's (in press) symbol zonation. A brief comparison is made with Lower Cretaceous fauna encountered in the Canadian Atlantic continental margin.

\section{RESULTS}

Sample 1, Lithologic Unit 2a; Zones N22-23Quaternary

Rich planktonic assemblage with Globorotalia crassaformis, $G$. hirsuta, $G$. inflata, G. menardii, $G$. truncatulinoides, Globigerina bulloides, G. pachyderma, Globigerinoides conglobatus, $G$. extremus, $G$. sacculifera, Globigerinita sp., Hastigerina aequilateralis, Orbulina universa, Sphaeroidinella sp.

Rich benthonic assemblage with Bolivina sp., Bulimina ?alazanensis, B. mexicana, Cibicides wuellerstorffi, Dentalina sp., Dorothia sp., Eggerella bradyi, Eponides umbatus, Epistomina elegans, Pyrgo murrhina, Sphaeroidina bulloides, Uvigerina hollicki, $U$. senticosa, Virgulina sp.

The planktonic zonation follows Blow (1969); the benthonic determinations are after Phleger et al. (1953), which lists most of the taxa occurring at abyssal depth in the North Atlantic Ocean.

\section{Sample 2, Lithologic Unit 2b; Probably Zone N16-Late Miocene}

Rich planktonic assemblage with Candeina nitida, Globorotalia acostaensis (frequent), G. obesa, G. scitula group, Globoquadrina dehiscens, G. altispira, Globigerinita uvula, Globigerinoides trilobus, Orbulina universa.

Among benthonic Foraminifera occur Bolivina sp., Bulimina mexicana, Eponides sp., Frondicularia sp., Gyroidina sp., Lenticulina sp., Stilostomella subspinosa, Rectuvigerina sp.

The planktonic zonation is after Blow (1969); benthonic determination follows Phleger et al. (1953) and Douglas (1974). The benthonic assemblage may be largely in situ and would be compatible with an abyssal depth.

Sample 3, Lithologic Units 3a, b-?Oligocene

Poor assemblage with Eponides umbonatus, Globorotalia aff. opima opima, Karreriella sp., Nonion pompilioides, Uvigerina aff. galloway. Radiolarians are frequent.

\section{Sample 4, Lithologic Unit 3b-Oligocene}

Poor assemblage with Chiloguembelina sp., Globigerina spp., Globorotalia aff. opima nana, G. aff. increbescens, Pseudohastigerina sp., and several benthonics including Eponides umbonatus.

\section{Sample 5, Lithologic Unit 3c-Eocene}

Relatively rich benthos assemblage with Anomalina sp., Cibicides sp., Gavelinella sp., Gyroidina girardana, Lenticulina sp., Nuttalides truempyi, Nodosaria sp., Rzehakina epigona, and several ostracode species.

Most specimens are stoutly build, are large in size, and might be derived from a high energy, shallow marine environment.

Sample 6, Lithologic Unit 5a; Zones UC1-UC2, EarlyMiddle Cenomanian

Moderately rich assemblage with the planktonics Globigerinelloides bentonensis, G. eaglefordensis, Hedbergella amabilis, $H$. delrioensis, $H$. planispira, Praeglobotruncana delrioensis, Rotalipora appenninica (ra); and the benthonics Gavelinella aff. spissocostata, $G$. aff. greenhornensis, Gyroidinoides sp., Marsonella oxycona, Pleurostomella obtusa. 
TABLE 1

Age of the Composite Samples Studied for Foraminifera at Site 370, DSDP Leg 41 and the Relation to the Lithology

\begin{tabular}{|c|c|c|c|c|}
\hline Age & $\begin{array}{l}\text { Composite } \\
\text { Samples } \\
\text { Studied }\end{array}$ & $\begin{array}{c}\text { Sample } \\
\text { (Interval in } \mathrm{cm} \text { ) }\end{array}$ & & Unit/Lithology \\
\hline Quaternary & 1 & $\begin{array}{l}1-3,80-82 \\
1-5,83-85\end{array}$ & $\begin{array}{l}1 \\
2 \mathrm{a}\end{array}$ & $\begin{array}{l}\text { Nanno-foram bearing clay } \\
\text { Clayey nanno ooze and marls }\end{array}$ \\
\hline Late Miocene & 2 & $2-2,65-67$ & $2 b$ & $\begin{array}{l}\text { Clayey nanno ooze with silt } \\
\text { and sand beds }\end{array}$ \\
\hline ? Oligocene & 3 & $\begin{array}{l}4-2,78-80 \\
5-2,68-70 \\
5-4,58-60\end{array}$ & $3 a$ & Nanno radiolaria-bearing clay \\
\hline Oligocene & 4 & $\begin{array}{l}7-2,88-90 \\
8-2,60-62 \\
10-2,54-55\end{array}$ & $3 b$ & $\begin{array}{l}\text { Calcareous silty clay with } \\
\text { porcellanite }\end{array}$ \\
\hline Eocene & 5 & $\begin{array}{l}14-1,66-68 \\
14-4,96-98 \\
16-3,130-132\end{array}$ & $3 \mathrm{c}$ & $\begin{array}{l}\text { Calcareous silty clay with } \\
\text { silt, sand, porcellanite, and } \\
\text { chert }\end{array}$ \\
\hline & & & 4 & Nanno marl \\
\hline Early-middle Cenomanian & 6 & $\begin{array}{l}20-1,78-80 ; 21-2,68-70 \\
20-3,68-70 ; 22-2,69-71\end{array}$ & & \\
\hline Albian-?Cenomanian & 7 & $\begin{array}{l}23-2,78-80 ; 26-1,78-80 \\
23-4,78-80 ; 26-4,78-80 \\
24-2,78-80\end{array}$ & $5 a$ & $\begin{array}{l}\text { Nanno-bearing claystone } \\
\text { grading into claystone }\end{array}$ \\
\hline$?$ & 8 & $\begin{array}{l}28-1,79-80 ; 28-4,69-70 \\
28-3,68-70 ; 30-2,98-100\end{array}$ & \multirow{5}{*}{$5 b$} & \multirow{5}{*}{$\begin{array}{l}\text { Calcareous silty claystone, } \\
\text { nanno-bearing claystone, } \\
\text { siltstones, and sandstones }\end{array}$} \\
\hline Barremian (-?Albian) & 9 & $34-3,78-90$ & & \\
\hline $\begin{array}{l}\text { Early Hauterivian- } \\
\text { Late Valanginian }\end{array}$ & 10 & $\begin{array}{l}38-4,113-115 \\
39-1,101-105 \\
41-3,69-71\end{array}$ & & \\
\hline $\begin{array}{l}\text { Early Hauterivian- } \\
\text { Late Valanginian }\end{array}$ & 11 & $\begin{array}{l}44-2,53-55 ; 45-4,22-24 \\
44-3,54-56 ; 49-1,50-52\end{array}$ & & \\
\hline$?$ & 12 & $50-2,52-59$ & & \\
\hline
\end{tabular}

The zone designation is after van Hinte (in press). The age is determined from the presence of Rotalipora appenninica and Praeglobotruncana delrioensis and the absence of Ticinella and Planomalina (compare Hermes, 1969; Moullade, 1966; van Hinte, in press).

\section{Sample 7, Lithologic Unit 5a; Zones LC14-17-Albian- ?Cenomanian}

Assemblage rich in the benthonics Glomospira aff. corona and Trochammina sp.; benthonics less common include Anomalina gracillima, Gavelinella sp., Gaudrina sp., Conorotalites aptiensis (ra), G1roidinoides primitiva, G. sp., Osangularia utaturensis (ra), Pleurostomella obtusa, and Spiroplectammina sp.

Planktonics are Globigerinelloides eaglefordensis. Hedbergella aff. amabilis, $H$. delrioensis, $H$. planispira. Praeglobotruncana delrioensis, and one specimen of what might be Ticinella sp.

Praeglobotruncana delrioensis suggests a late Albian or somewhat younger age (Moullade, 1966); the occurrence of Conorotalites aptiensis, Osangularia utaturensis, and Pleurostomella obtusa indicates older Albian strata (see Moullade, 1966; Simon and Bartenstein, 1962; Scheibnerova, 1974). The discrepancy may be due to the condensed sample.

\section{Sample 8, Lithologic Unit 5b-Not Age Diagnostic}

Few specimens of simple arenaceous Foraminifera.
Sample 9, Lithologic Unit 5b; Zone LC8-Barremian (to ?Albian)

Relatively poor assemblage with the planktonics ?Favusella washitensis (two specimens, badly preserved), Hedbergella planispira, $H$. spp.; among the benthonics occur Dentalina gracilis, Gavelinella barremiana, $G$. aff. intermedia.

Gavelinella barremiana is commonly regarded as a Barremain-early Aptian marker (e.g., Michael, 1966; Moullade, 1966; Simon and Bartenstein, 1962). Van Hinte (in press) restricts the species to the Barremian. Dentalina gracilis, according to Bartenstein et al. (1957), occurs in Barremian-Albian beds. The presence in sample 9 of several small Hedbergellids, and the absence of Ticinella and Globigerinelloides may be indicative of Barremian strata. Favusella washitensis is thought to be of post Barremian, or even post Aptian age (e.g., van Hinte, in press); the specimens could be cavings or have been misidentified.

Sample 10, Lithologic Unit 5b; Zones LC4-LC5-Late Valanginian-Early Hauterivian

The few benthos include Citharina sp., Epistomina caracolla, Gavelinella ?barremiana (presumably caved fragment), Lenticulina saxonica, $L$. spp., Lingulina sp., Saracenaria bronni. There are several ostracode shells.

Lenticulina saxonica, according to Simon and Bartenstein (1962), indicates a late Valanginian-early 
Hauterivian age. This age agrees with the absence of planktonic Foraminifera (e.g., van Hinte, in press). An exception is the presence of one pyritized mold of ?Gubkinella sp. Church (1958) and Dailey (1973) report this genus from the ?Hauterivian to Barremian of California.

The absence of planktonic Foraminifera in preHauterivian beds is not absolute. On the Scotian Shelf the simple planktonic Globigerina hoterivica Subbotina occurs in ?Valganinian-Hauterivian beds (P. Ascoli, personal communication).

Small planktonics, described under several names are relatively common in Middle-Upper Jurassic beds of Europe, Eurasia (see Gorden, 1970), and the Grand Banks of Newfoundland (Gradstein, in press).

\section{Sample 11, Lithologic Unit 5b; Zones LC4-LC5-Late Valanginian-Early Hauterivian}

Benthonic Foraminifera only, including Citharina harpa, Dorothia praehauteriviana, Lenticulina crepidularis, L. busnardoi, L. matutina, L. saxonica, Marsonella sp., Saracenaria cf. bononiensis, Vaginulina kochi.

From the ranges of the species in Bartenstein et al. (1957), Simon and Bartenstein (1962), Moullade (1966), a late Valanginian-early Hauterivian age is likely.

\section{Sample 12, Lithologic Unit 5b}

Barren of Foraminifera.

\section{COMPARISON WITH THE LOWER CRETACEOUS OF THE CANADIAN ATLANTIC MARGIN}

The Lower Cretaceous microfauna of the Scotian Shelf and Grand Banks, Canadian Atlantic margin is relatively diversified, with many species and specimens. Many of the wells penetrating beds of this age contain specimens of larger benthonic Foraminifera (Choffatella, Pseudocyclammina, and occasionally Orbitolina) and a varied ostracode fauna; among the smaller benthonic Foraminifera, epistominids and simple arenaceous taxa (e.g., Haplophragmoides and Marsonella) are common to abundant in some wells; the epistominids favor shales. Nodosariidae (sensu Loeblich and Tappan, 1964) and gavelinellids are not uncommon; Conorotalites and planktonics are common in a few wells only (Williams et al., 1974; Jenkins, et al., 1974; Gradstein et al., 1975; P. Ascoli, personal communication).

By comparison the Site 370 Lower Cretaceous beds do not contain larger Foraminifera and are almost devoid of epistominids and ostracodes. Other differences are the presence in Core 370-7 of Glomospira, Pleurostomella, and Osangularia, which have not been recorded from the Canadian Atlantic Shelf Lower Cretaceous strata.

From the microfauna, sedimentology and geology of the Canadian Atlantic Shelf, the Lower Cretaceous deposits are thought to be of a shallow marine nature (Gradstein et al., 1975; Jansa and Wade, 1975), water depth may have been mostly shallow neritic.

The Lower Cretaceous beds of Site 370 appear to have been deposited at greater depth (bathyal) with sedimentologic evidence for a shelf-derived origin of part of the sediment (L.F. Jansa, personal communication). It is possible that the microfauna is also partially reworked from a shelf but this is not clear from our small samples.

The absence of larger Foraminifera and the rarity of epistominids and ostracodes at Site 370 appear to be the main differences with the Canadian Atlantic Shelf Lower Cretaceous. The absence of larger Foraminifera may be attributed to bathyal conditions with no sediment derived from a (very) shallow neritic source. The rarity of Lower Cretaceous epistominids may also be due to the deeper water nature of Site 370 sediments, an explanation favored by Maync (1971) for their absence from Lower Cretaceous beds at Site 120 on Gorringe Banks off Portugal.

\section{REFERENCES}

Bartenstein, H., Bettenstaedt, F., and Bolli, H.M., 1957. Die Foraminiferen der Unterkreide von Trinidad, B.W.I. Erster Teil: Cuche and Toco-Formation: Eclog. Geol. Helv., v. 50, p. 5-65.

Blow, W.H., 1969. Late middle Eocene to Recent planktonic foraminiferal biostratigraphy: Ist Intern. Conf. Plankt. Microfossils, Proc. Geneva 1967, v. 1: Leiden (Brill), p. $199-422$.

Church, C.C., 1968. Lower Cretaceous Foraminifera of the Orchard Peak Devils Den area, California: Calif. Acad. Sci. Proc., ser. 4, v. 32, p. 523-580.

Dailey, D.H., 1973. Early Cretaceous Foraminifera from the Budden Canyon Formation, northwestern Sacramento Valley, California: Univ. California Press, Geol. Sci., v. 106, p. $1-111$.

Douglas, R.G., 1974. Benthonic foraminiferal biostratigraphy in the Central North Pacific, Leg 17, Deep Sea Drilling Project. In Winterer, E.L., Ewing, J.L., et al. Initial Reports of the Deep Sea Drilling Project, Volume 17: Washington (U.S. Government Printing Office), p. 607-672.

Gordon, W.A., 1970. Biogeography of Jurassic Foraminifera: Geol. Soc. Am. Bull., v. 81, p. 1689-1704.

Gradstein, F.M., Williams, G.L., Jenkins, W.A.M., and Ascoli, P.A., 1975. Mesozoic and Cenozoic stratigraphy of the Atlantic continental margin, eastern Canada: Canadian Soc. Petrol. Geol., Mem 4, p. 103-133.

, in press. Biostratigraphy and biogeography of Jurassic Grand Banks Foraminifera: Proc. "Benthonics 1975," Halifax (N.S.), Canada.

Hermes, J.J., 1969. Late Albian Foraminifera from the subbetic of southern Spain: Geol. Mijnb., v. 48, p. 35-67.

Jansa, L.F. and Wade, J.A., 1975. Geology of the continental margin off Nova Scotia and Newfoundland: Geol. Surv. Can. Paper 74-30, v. 2, p. 51-103.

Jenkins, W.A.M., Ascoli, P., Gradstein, F.M., Jansa, L.F., and Williams, G.L., 1974. Stratigraphy of the Amoco IOE A-1 Puffin B-90 well, Grand Banks of Newfoundland: Geol. Surv. Can. Paper 74-61, p. 1-9.

Loeblich, A.R. and Tappan, H., 1964. Treatise on invertebrate paleontology. In Moore, R.C. (Ed.), Pt. c, Protista 2 (Sarcodina, chiefly Thecamoebians and Foraminiferida), v. 1, p. 2.

Maync, W., 1971. Lower Cretaceous foraminiferal fauna from Gorringe Bank, eastern North Atlantic. In Ryan, W.B.F., Hsü, K.J., et al. Initial Reports of Deep Sea Drilling Project, Volume 13: Washington (U.S. Government Printing Office), p. 1075-1112. 
Michael, E., 1966. Die Evolution der Gavelinelliden (Foram.) in der N.W. deutschen Unterkreide: Senckenb. Leth., v. 47 , p. $411-459$.

Moullade, M., 1966. Etude stratigraphique et micropaleontologique du Cretacé inferieur de la 'Fosse Vocontienne': Doc. Labo. Geol. Fac. Sci. Lyon, no. 15, fasc. 1, 2, p. 369.

Phleger, F.B., Parker, F.L., and Peirson, J.F., 1953. North Atlantic core Foraminifera: Rept. Swedish Deep Sea Exped., v. 7, p. 1-222.

Schiebnerova, V., 1974. Aptian-Albian benthonic Foraminifera from DSDP Leg 27, Sites 259, 260 and 263, eastern Indian Ocean. In Veevers, J.J., Heirzler, J. R. et al., Initial Reports of Deep Sea Drilling Project, Volume 27: Washington (U.S. Government Printing Office), p. 697741.

Simon, W. and Bartenstein, H., 1962. Leitfossilien der Mikropaläontologie: Berlin (Gebr. Borntraeger).

van Hinte, J.E., in press. A Cretaceous time scale: Am. Assoc. Petrol. Geol. Bull.

Williams, G.L., Jansa, L.F., Clark, D.F., and Ascoli, P., 1974. Stratigraphy of the Shell Naskapi N-30 well, Scotian Shelf, Eastern Canada: Geol. Surv. Can. Paper 74-50, p. 1-12. 